http://journals.ums.ac.id/index.php/ijolae

\title{
The Tendency Towards Entrepreneurship Among Students of Maktab Rendah Sains Mara (MRSM)
}

\author{
Nordalila Mohammad Rasid ${ }^{1}$, Nor Aishah Buang ${ }^{2}$ \\ ${ }^{1,2}$ Faculty of Education, National University of Malaysia, Malaysia
}

DOI: 10.23917/ijolae.v1i1.7287

Accepted: December $8^{\text {th }}, 2018$. Approved: February $18^{\text {th }}, 2019$. Published: February $21^{\text {st }}, 2019$

\begin{abstract}
In this globalization's era, entrepreneurship is one of the catalyst that related to the economy, enhancing innovation, creativity and competitive for a country. Based on that scenario, the entrepreneurial field today is developing rapidly in our country Malaysia through our educational system. So, this research was carried out to find out the tendencies among the students of Maktab Rendah Sains MARA (MRSM) in the field of entrepreneurship. This research was using descriptive method through quantitative approach. The questionnaire used as the research instrument by using the Likert Scale. All the data s obtained then analyzed using the Statistical Packages for Social Sciences (SPSS) version 22. All the respondent were 108 students of MRSM who had been chosen by simple random. The result showed that attitude was the main dimension that influenced student to be involve in entrepreneurship. Beside that, the result also showed that there was no slightly significant differences in the item of gender factor in entrepreneurship tendency among those students.
\end{abstract}

Keywords: Entrepreneurship tendency, MRSM, entrepreneurship attitude

Corresponding Author:

Nordalila Mohammad Rasid, Faculty Pendidikan National University of Malaysia, Makaysia

Email: didies78@gmail.com

\section{Introduction}

Entrepreneurship is one of the main field

for a country's development. It is able to reduce the jobless rate, poverty and also the job opportunities if it is used as a medium for increasing the country's economy (Ravi 2015). On September 2017, the rate of jobless was same as last month by $3.4 \%$ with a $0.1 \%$ decreased on September 2016. While the adjustment for this rate on September 2017 was $3.5 \%$, increased by $0.1 \%$ compared to last month (Jabatan Perangkaan Malaysia, 2017). This jobless rate can be solved by choosing entrepreneurship as the chosen carrier.

However, this field still cannot be a chosen carrier (Hafeza, 2012). Furthermore, this type of carrier in the future is still in the intermediate rate (Azmi, 2012). This shows that students nowadays are still not aware about the job chances in entrepreneurship (Norasmah et al. 2012).

Based on this problem, Majlis Amanah Rakyat (MARA) implemented entrepreneurship programs in order to nature and exposed the students of Maktab Rendah Sains MARA (MRSM) about the basics in entrepreneurship among them. It was done so to nature, develop and open the opportunities for learning and practising the principles of entrepreneurship among them so that they can choose entrepreneurship as their main carrier soon.

The percentage of the after school students and university graduates who chooses entrepreneurship as their carrier was still low (Wan Mohd Zaifurin et al. 2016). 
Then, the students who got experiences in entrepreneurship from secondary school seem to got awareness and entrepreneurship tendency earlier then others (Mohd et al. 2016). From this entrepreneurship programmers, it managed to influence the development of psychology and cognitive abilities in entrepreneurship activities (Liliana 2014; Rosna Mohamad, Norasmah 2016) because the psychology factor showed the higher rate of entrepreneurship tendency (Jeraj \& Maric 2013).

However, the problem now is the entrepreneurship programme that been offered did not managed to develop students to think the way of an entrepreneur. Students still have problems in understanding the real contexts of entrepreneurship. Kajian Unit Kaunseling dan Kerjaya Bahagian Pelajaran dan Latihan Menengah MARA (BPLM) through a test named "Self Directed Search" (SDS) said that almost all MRSM's students did not choose entrepreneurship as thier main carrier (MARA, 2015). This situation did not represent the real Majlis Amanah Rakyat (MARA)'s motto itself which is "Culturing the Entrepreneurship as the Chosen Carrier" (Membudayakan Keusahawanan Sebagai Kerjaya Pilihan). So, is all the programme related to entrepreneurship itself did not managed to attract students?

So, this research had been carried out in order to recognize the rate of tendency for entrepreneurship among MRSM's students and the differences in the rate based on gender. It is hope that the result from this research will give some inputs of ideas and references for next researchers in the future.

Entrepreneurship activities are among the factors that can influences the tendency of entrepreneurship itself. There are a lot of research's had been done to determine the tendency of entrepreneurship among citizens especially among students. In order to produce an entrepreneur, he or she does not only to have a natural personalities but they also influenced by the other factors such as skills, family members and also experiences (Ab. Aziz, 2015).

A person tendency in anything can be pushed by their eagerness to get something. If the he or she has a tendency for entrepreneurship so the probability for he or she to get himself or herself involved in entrepreneurship field will be higher. This means that the chances for that particular person to have tendency in choosing carrier in entrepreneurship will be higher if the he or she has a positive thinking and very eager to involved in that field. The past research had proven that positive attitudes can stimulate the rate of curiosity for a person to show of the next action by choosing entrepreneurship as a carrier. This statement had been recognized by Hisrich et al. (2008) when he believed that every person that have a strong tendency to do something will show the positive probability toward what he or she want.

However, the rate in tendency of students involved in entrepreneurship field is different. This is based on the Organized Behavior Theory (Teori Perlakuan Terancang, TPT), where the human behavior can be predicted by identifying the true intentions to do some particular thing (Engle et al. 2010). In the TPT, it has three variables that can influences a person's tendency which are attitude, subjective norma and impression of the behavior's control (Ajzen, 1991).

But, in this research covered only the elements of controlled thought of behavior (interest, attitude and desire) towards the tendency for entrepreneurship. The attitude and knowledge in entrepreneurship, both can increase student's interest in entrepreneurship world (K,Wang, 2004). Beside that, family background also can generate the individual 
interest and tendency in entrepreneurship. Based on the research conducted by Scoot (1988), family that run a business will influence the tendency of entrepreneurship itself among the other family members. This was supported by Kristiansen \& Indarti (2004) research where they stated that the factor of family background and experiences both influence the tendency in entrepreneurship but contradicts with Osman (2007) where in his research stated that family background did not influences the tendency in entrepreneurship.

Now, entrepreneurship education had been implemented by government to encourage Malaysian citizens to involve themselves in entrepreneurship especially in the secondary school in order for shaping students' attitude so they can create the job for themselves and not as a job hunters (Wan Muhammad Zaifurin et al. 2016). This is because the involvement and exposure among students in the entrepreneurship form of activities in school had been proven to generate desire among students in entrepreneurship field (Ahzilah, Norasidah \& Namlus 2017). Siti Syuhada, Muhammad Firdaus \& Suhaila (2015) stated that competency, self control, self confidence and creative and innovative mind among students had been increased after they joined any entrepreneurship programme. Then, Ahzilah, Norasidah \& Namlus (2017) mentioned that entrepreneurship education had been proven in increasing students' ability in analyzing the problems properly. In the same time, their involvement in entrepreneurship activities can spark some of the curiosity, motivation and interest in entrepreneurship (Rosli, 2013).

So, this research is to find out how the rate of tendency in entrepreneurship among students of MRSM through some of the factors such as interest, attitude and desire.

\section{Method}

Methodology is one of the important aspect in ensuring the goals of a research to be achieved. The design of this research is a survey research which is in form of descriptive where all the information were collected from the respondents to observe the tendency factors among MRSM students in entrepreneurship. The research population is 150 MRSM students. Based on the sample size determination Krejcie and Morgan (1970), sample size that had been chosen is 108 respondents.

The instrument used was questionnaire that has two sections which is A dan B. Section A contains 4 items related to the respondents background while section B with 15 items covered the accepts of interest, attitude and desire towards entrepreneurship. The questionnaire set can be see Table 1 .

Table 1. The Content of The Questionnaire

\begin{tabular}{lll}
\hline Section & Details & Item \\
\hline A & Respondent Demography & 3 \\
& Interest & 5 \\
B & Attitude & 5 \\
& Desire & 5 \\
\hline
\end{tabular}

The items in section B used the five marks Likert Scale assessment which is number 1,2,3,4 and 5 to represent whether the respondent agree or not about the question
(Chua, 2006). Below shows the five marks Likert Scale ranking used in this research. 
Table 2. Assessment Sckale Towards the Items in Section B

\begin{tabular}{cl}
\hline Scale & Assessment \\
\hline 1 & Strongly Disagree \\
2 & Disagree \\
3 & Neutral \\
4 & Agree \\
5 & Strongly Agree \\
\hline
\end{tabular}

A pilot study had been done towards 30 MRSM students who have been choosen randomly to get a validity and trustworthiness questionnaire. By this pilot study, researcher manage to know the comments and suggestions in order to improve the items used in this questionnaire. The questionnaire trustworthiness for this research determined by the value of Realibility Cronbach's Alpha that gained from the SPSS software. So, all the raw data obtained from the pilot study was been analysised. The alpha value was been analysised totaly and separately according to the variable factors of the research. The result showed reliability coefficient, alpha value for the whole item built was 0.781. Creswell (2012) mentioned that the result for Cronbach Alpha value which exceed 0.80 and above can be accepted. This shows that the validity and trustworthiness for questionnaire used is high and satisfying to be conduct in a real study. So, this measurement is accepted and had been used in the real study.

The data analysis about the rate of tendency in entrepreneurship involed the frequency, percentage, min score and standard deviation. All the datas obtained were quanti- tative. In this research, the analysis data methodologies used were frequency score (f), percentage (\%) and min which is descriptive statistic analysis and T-test. The min value intrepertation based on the scale used by Rahimah (2006), which was score value $1.00-$ 2.33 low, $2.34-3.67$ medium and $3.68-5.00$ high.

\section{Result and Discuss}

This part is to determine all the results and information related by the respondent demographic. This demography was been analyzed using the frequency and percentage. Table 3 below shows the result about the demography of the all respondents in MRSM. Based on the gender, 72 for female students with $66.67 \%$ and 36 for male students with $33.33 \%$. For the family background who involved in entrepreneurship, 23 students with $21.30 \%$. While 85 students with $79.63 \%$ their families did not involved in entrepreneurship. Next, the tendency for them to involve in entrepreneurship, 33 students with $30.56 \%$ like to work with salary while 75 students with $69.44 \%$ prefer to involved in entrepreneurship. The table below shows the demo graph for all respondents.

Table 3. Respondent Demography

\begin{tabular}{llll}
\hline Item & Adverb & Frequency & Percentage \\
\hline Gender & Male & 36 & $33.33 \%$ \\
& Female & 72 & $66.67 \%$ \\
\multirow{2}{*}{ Family Background } & Do Business & 23 & $21.30 \%$ \\
& Does not do Business & 85 & $79.63 \%$ \\
\multirow{2}{*}{ Carrire Choosed } & & & \\
& Self Employed & 75 & $69.44 \%$ \\
& Salary Worker & 33 & $30.56 \%$ \\
\hline
\end{tabular}

To Determine the Rrate of Tendency in Student Entrepreneurship Among MRSM Students. 
Table 4 below shows min and percentage for student interest, attitude and desire in entrepreneurship. Study by Salmianti (2014), stated that tendency mean interest, intentions, likeness or what a person want. The intention to try anythings in a specific field can be used to determine what are the field that a person will be involved. The result showed that interest in entrepreneurship recorded the highest min value ( $\min =4.26, \mathrm{SD}=.782$ ) with $90.7 \%$ respondents agreed and strongly agree. Then, followed by involving in entrepreneurship activities with $\min$ value $=4.14$ and $\mathrm{SD}=.633$. About $74.3 \%(\mathrm{~m}=4.13, \mathrm{SD}=.810)$ of the respondents always see the advertisement about entrepreneurship programme to find a suitable business. Then, respondents who said that they were suitable for entrepreneurship with min 4.02 ( $\mathrm{SD}=.529)$. Beside that, respondent also did not discuss more about this because the min value just only 3.99 ( $\mathrm{SD}=.690)$ with $75.9 \%$. Although the respondents showed a high interest in entrepreneurship, however they said that their knowledge about the entrepreneurship issues were still low. This happened because they did not get a enough exposure about entrepreneurship. The teachers in MRSM also can plan some activities in form of collaborative and cooperative learning about entrepreneurship (Normah dan Ruhaiza (2014). Entrepreneurship programme that often held can be able to show the entrepreneurship culture and high interest among MRSM students.

Table 4. Frequency and Percentage of MRSM Students in Loading Demension

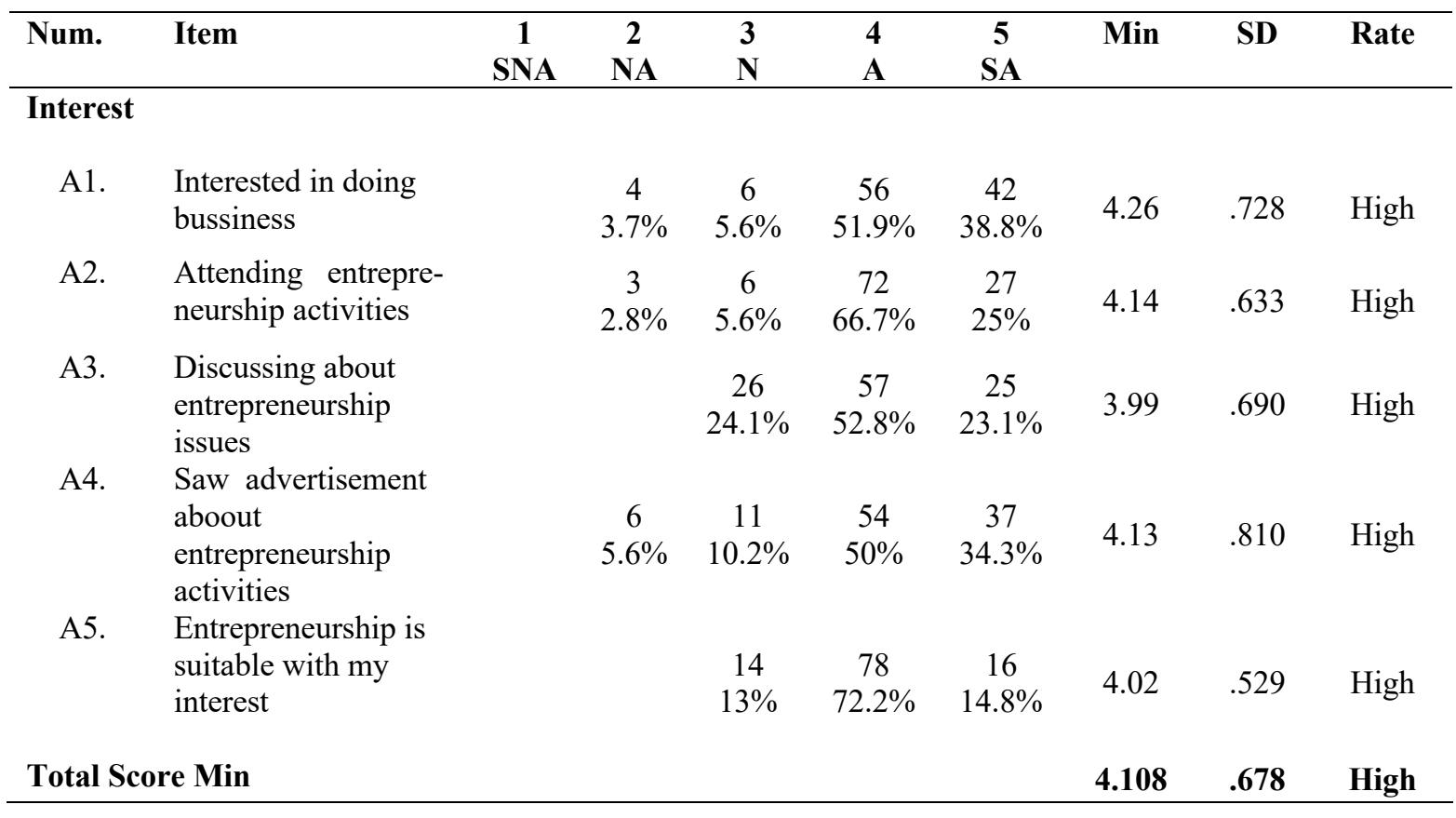

Based on the Table 5, the attitude to meet with any successful entrepreneur has the highest min score with $4.38(\mathrm{SD}=.488)$ with $100 \%$ agree and strongly agree. Then followed by mingle with entrepreneur with min score $4.43(\mathrm{SD}=.653)$. Next, attending any social programme with min value 4.20 $(\mathrm{SD}=.794)$. Grab the job opportunities with attending entrepreneurship expos with min value $4.12(\mathrm{SD}=.652)$ and finally min value $4.09(\mathrm{SD}=.322)$ for those who always finding job in business. This finding shows that there are students who did not interested in entrepreneurship with a high min score. For MRSM administration, they should improve the entrepreneurship activities so that it can be 
more attractive such as bring students to the real live of an entrepreneur by attending business expos and meet any successful entrepreneur.

Table 6 shows the desire for entrepreneurship career with the highest min value with 4.29 ( $\mathrm{SD}=.612)$ with $93.5 \%$ agree and not agree. Followed by desire to achieve dream, with min value $4.28(\mathrm{SD}=.470)$ with
99.1\% agree and strongly agree. Then, dream to be a young entrepreneur and having own business, both min value are $4.22(\mathrm{SD}=.518)$ and $4.19(\mathrm{SD}=.571)$. Success in business, got the lowest min value with $4.06(\mathrm{SD}=.230)$ but still recorded with the highest percentage which is $100 \%$ respondents agree and strongly agree.

Table 5. Frequency and Percentage of MRSM Students Regarding Attitude Dimension

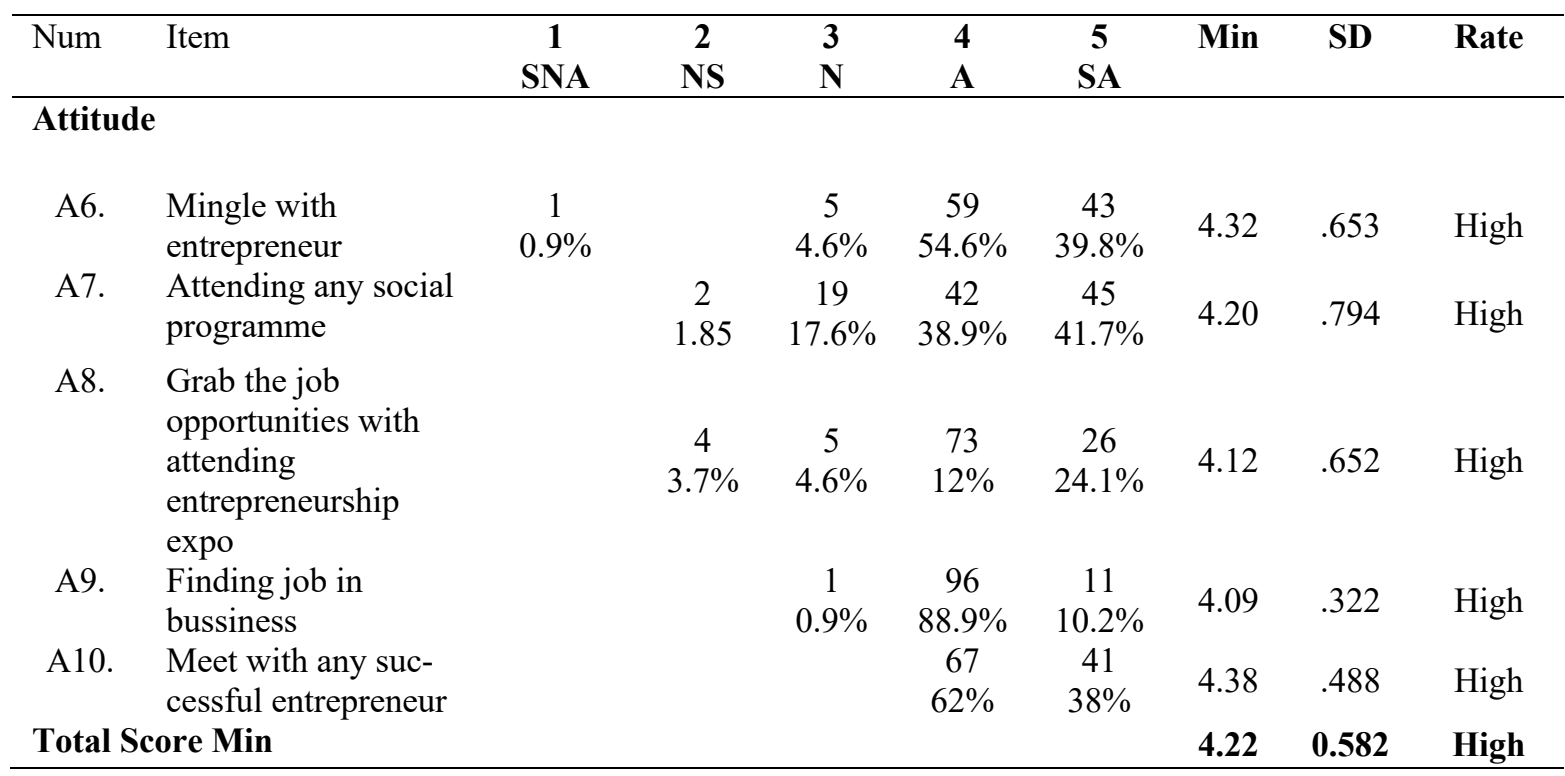

Table 6. Frequency and Percentage of MRSM Students Regarding Desire Dimension

\begin{tabular}{llcccccccc}
\hline \multirow{2}{*}{ Num } & \multicolumn{1}{c}{ Item } & $\mathbf{1}$ & $\mathbf{2}$ & $\mathbf{3}$ & $\mathbf{4}$ & $\mathbf{5}$ & \multirow{2}{*}{ Min } & SD & Rate \\
\hline Desire & & & NA & $\mathbf{N}$ & $\mathbf{A}$ & $\mathbf{S A}$ & & \\
A11. & Entrepreneurship career & & 1 & 6 & 62 & 39 & 4.29 & .612 & High \\
& & & $0.9 \%$ & $7.4 \%$ & $57.4 \%$ & $36.1 \%$ & & & \\
A12. & Having own business & 1 & & 3 & 77 & 27 & 4.19 & .571 & High \\
& & $0.9 \%$ & & $2.8 \%$ & $71.3 \%$ & $25 \%$ & & & \\
A13. & Desire to achieve dream & & & 1 & 76 & 31 & 4.28 & .470 & High \\
& & & $0.9 \%$ & $70.4 \%$ & $28.7 \%$ & & & \\
A14. & To be a young entrepreneur & & & 5 & 74 & 29 & 4.22 & .518 & High \\
& & & $4.6 \%$ & $68.5 \%$ & $26.9 \%$ & & & \\
A15. & Success in bussiness & & & 102 & 6 & 4.06 & .230 & High \\
\multicolumn{1}{l}{ Total Score Min } & & & & $94.4 \%$ & $7.4 \%$ & & & \\
\hline
\end{tabular}

Based on Table 7 below, the factor of the students' attitude towards entrepreneurship has the highest rate with min score 4.220 followed by their desire toward entrepreneurship with 4.208 and their interest with 4.108. This shows that the attitude factor is the main factor that influences students towards entrepreneurship.

So, overall we can see that the students have their own potential of entrepreneurship. 
Entrepreneurship activities should be done in order to spark their interest, attitude and desire. This should be a challenge to the school administration to make it real beside giving them motivation so that they can wisely determine the opportunities and finally manage to make entrepreneurship as their career in the future.

Table 7. Factors that Influenced Tendency Towards Entrepreneurship Among MRSM Students

\begin{tabular}{clccc}
\hline Num & \multicolumn{1}{c}{ Construct } & Min Score & $\begin{array}{c}\text { Standard Devia- } \\
\text { tion }\end{array}$ & $\begin{array}{c}\text { Score Min } \\
\text { Rate }\end{array}$ \\
\hline 1 & $\begin{array}{l}\text { The tendency of interest in } \\
\text { entrepreneurship }\end{array}$ & 4.108 & .678 & High \\
2 & $\begin{array}{l}\text { The tendency of attitude in } \\
\text { entrepreneurship }\end{array}$ & 4.220 & .582 & High \\
3 & $\begin{array}{l}\text { The tendency of desire in entrepreneurship } \\
\text { Average }\end{array}$ & 4.208 & .480 & High \\
& $\mathbf{4 . 1 7 9}$ & $\mathbf{. 5 8 0}$ & High \\
\hline
\end{tabular}

The Differences Between the Tendency of Entrepreneurship Based on Gender

Table 8. The Tendency of Entrepreneurship Based on Gender

\begin{tabular}{llccccc}
\hline T test & & Min & $\begin{array}{c}\text { Standard De- } \\
\text { viation }\end{array}$ & Value of -t & $\begin{array}{c}\text { Rate of Signifi- } \\
\text { cant }\end{array}$ \\
\hline Gender & & & & & & \\
& Male & 36 & 4.220 & .140 & .900 & .345 \\
& Female & 72 & 4.148 & .171 & & \\
\hline
\end{tabular}

Based on the Table 8 , min value for male student are higher than female students which is $4.220(\mathrm{SD}=.140)$ while min for female students is $4.148(\mathrm{SD}=.171)$. However, the T-test (Independent Sample Test) that has been carried out showed that there is no significant differences where the value $p>0.05$ for the item that measure the tendency towards entrepreneurship based on gender. This means that there is no differences for the item that measure the tendency towards entrepreneurship based on gender.

\section{Conclusion}

As the conclusion, this research had answered both objective that had been forwarded in order to determine the rate of tendency towards entrepreneurship among MRSM students. The factor of attitude is the main factor that influence students towards this entrepreneurship field. The involvement in entrepreneurship activities can shape their attitude to tend towards entrepreneurship. Students should involve themselves in any entrepreneurship activities so that they can show their ability and characteristics of an entrepreneur such as attitude, thought and behavior in the highest manner (Azmi .2012).

This research also can be propose to be a guidance for the next researchers, lectures and any stakeholders in order to develop more student entrepreneurs both from school leavers and also graduates. So, it is hope that all MRSM students will get a lot of benefits from entrepreneurship. By this way, it can help to enhance our country economy in this globalization era.

\section{References}

Ab. Aziz, Y. (2015). Teori dan amalan keusahawanan. Kuala Lumpur: Dewan Bahasa dan Pustaka.

Ahmad Mahdzan, A. (2015). Kaedah penyelidikan sosioekonomi (3 $3^{\text {th }}$ d.). Kuala Lumpur: Dewan Bahasa dan Pustaka.

Krejcie, R.V. \& Morgan, D.W. (1970). Determining Sample Size For Research Activities.

Krueger, N.F. \& Carsrud, A.L. (1993). Entrepreneurial Intention: Applying the Theory of Planned Behaviour. Entrepreneurship \& Regional Development, 5, 315330. Kuratko, D.F. \& Hodgetts, R.M. 
(1996). Entrepreneurship, A Contemparary Approach. Thirth Edition, London: Dryen Press.

Mohd Mustafa, U. A., Mohd Daud, S., Mohd Senon, M. dan Mohd Ismail,N.B.(2013). Kecenderungan Kerjaya Sebagai Usahawan Dalam Kalangan Pelajar Bumiputera Tahun Akhir Diploma Perniagaantani, Kolej Profesional Mara Beranang. Seminar Pasca Siswazah Dalam Pendidikan (GREDUC).

Mohd Rosli, F. (2013). Pembudayaan Keusahawanan Kearah Mempengaruhi Kecenderungan Menceburi Bidang Keusahawanan Dalam Kalangan Bakal Graduan di UTHM. Universiti Tun Hussein Onn Malaysia: Tesis Sarjana.

Noorkartina, M., Lim, H.-E., Norhafezah, Y., \& Soon, J.-J. (2015). Estimating the effect of entrepreneur education on graduates' intention to be entrepreneurs. Education + Training, 57(8/9), 874-890. http://doi.org/10.1108/ET-03-2014-0030

Nor Aishah Buang (2002). Asas Keusahawanan. Fajar Bakti. Polygraphic (M) Sdn. Bhd.

Nor Asikin, A. (2012). Penglibatan pelajar dalam aktiviti keusahawanan di koperasi sekolah. Universiti Pendidikan Sultan Idris.

Norasmah Othman (2011) Kecenderungan Terhadap Pemilihan Kerjaya Keusahawanan Mengikut Persepsi Peserta Skim Usahawan Siswa Jurnal Teknologi, 56 (Sains Sosial), 47-63 Retrieved from https://www.researchgate.net/publication $/ 314555872$

Norasmah Othman, O. Nor Hafiza, P.B Tin (2012) Impak Globalisasi dan Tingkah
Laku Pemilihan Kerjaya Keusahawanan dalam Kalangan Pelajar Universiti, Jilid $1,435-445$

Norfadhilah, N., \& Halimah, H. (2010). Aspirasi kerjaya keusahawanan dalam kalangan pelajar institusi Pengajian Tinggi Awam. Jurnal Pendidikan Malaysia, 35(1), 11-17.

Nur Zafirah Abd Rahim (2017). Impak Kursus Keusahawanan Terhadap Kecenderungan Pelajar Dalam Pemilihan Kerjaya Keusahawanan. Universiti Kebangsaan Malaysia.

Ravi AlP Nagarathanam, 2015.Hubungan Sikap, Pemikiran dan Tingkah aku Terhadap Keinginan dalam Pemilihan Kerjaya Keusahawanan Dalam Kalangan Pra Siswazah India Di Institut Pengajian Tinggi Sekitar Bangi; Tesis Fakulti Pendidikan UKM.

Salmianti Binti Mutalib (2014). Tinjauan Kecenderungan Keusahawanan Dalam Kalangan Pelajar Di Institusi Pengajian Tinggi Awam. Kolej Komuniti Bandar Penawar, Bandar Penawar, Johor, Malaysia.

Yusof Boon \& Sapiah Bohari. (t.t). Kesediaan untuk menceburi bidang keusahawanan di kalangan pelajar-pelajar bumiputera tingkatan empat di tiga buah sekolah sekitar Skudai, Johor. Universiti Teknologi Malaysia.

Zulfaka Ishak, Nor Aishah Buang \& Lilia Abd. Halim. (2011). Ciri-ciri dan tahap pemikiran Sains Keusahawanan: Kesediaan integrasi pemikiran keusahawanan dalam proses pengajaran guru-guru Sains di MRSM. Jurnal Kepimpinan Pendidikan Bil. 1 (1) 